\title{
Intelligent controller based power quality improvement of microgrid integration of photovoltaic power system using new cascade multilevel inverter
}

\author{
Gaddala Jayaraju', Gudapati Sambasiva Rao ${ }^{2}$
}

${ }^{1}$ Research Scholar, EEE Department, UCET, Acharya Nagarjuna University, India

${ }^{2}$ EEE Department, R.V.R. \& J.C, India

\begin{tabular}{l} 
Article Info \\
\hline Article history: \\
Received May 27, 2018 \\
Revised Nov 20, 2018 \\
Accepted Dec 9, 2018 \\
\hline
\end{tabular}

Keywords:

Photovoltaic cell

Power quality

Multilevel inverter

ANFIS

\begin{abstract}
Now a day the power demand has a major problem for developing countries due to the growth of population, industries, IT companies and other needs. In this present situation the fossil fuel-based power generation alone does not support the consumer needs, poor power quality due to nonlinear function and very harmful for environment. The main objective of this paper is improving the power quality of grid connected photovoltaic power system through a new cascade H-bridge multilevel inverter. The proposed research work has been modelled and controlled by ANFIS intelligence in MATLAB simulation environment. The simulation results are analysed under various operating conditions for improve the performance of proposed system. Finally, the proposed system THD value of simulation results is compared with IEEE 1547 standard for prove the effectiveness of proposed research work.
\end{abstract}

Copyright (c) 2019 Institute of Advanced Engineering and Science. All rights reserved.

\section{Corresponding Author:}

Gaddala Jayaraju,

Research Scholar, Department of Electrical and Electronics Engineering,

University College of Engineering \& Technology,

Acharya Nagarjuna University,

Nagarjuna Nagar, Guntur - 522 510, Andhra Pradesh, India.

Email: jayaraju2006@gmail.com

\section{INTRODUCTION}

In recent years dramatic improvements in energy generation due to the growth of population, development of new Industries and others need [1]. The power generated by using fossil fuels causing environmental issues and produce very harmful greenhouse gases, finally depletion of energy resources [2], [3]. This has led to an incredible growth of concentration in photovoltaic energy-based power generation. However, the stochastic fluctuation of PV power penetrates into the microgrid, owing to dissimilarities ranges of solar irradiation and temperature. The cascade multilevel inverter has a major contribution to penetrate the distributed generation power into microgrid [4], [5]. The transformerless multilevel inverters topologies have played the very important role due to their merits such as simplicity, highly effective, low switch usage and occupy less space [6], [7]. The microgrid integration of photovoltaic power technology by using CMHB inverter is comparatively of high merits and environmental benefits of power conversion technology [8], [9]. The microgrid power quality issue are major challenges in common installation of control design such as active power filters, voltage regulators and automatic current regulator, etc. increasing integration of renewable generation into the distributed AC power grid can cause voltage fluctuations and protection issues. These will increase the challenge of utility grid reliability and power quality [10], [11]. This paper has been disused as follows, in section 2 the mathematical model of photovoltaic power system has been presented. In section III design and simulation of proposed nine level new CMHB inverter by using in Matlab. Section IV presents modelling of ANFIS intelligent controller for 
grid integration of photovoltaic power system by using proposed inverter. Finally, the conclusion of this paper has been discussed in section $\mathrm{V}$.

\section{PV MATHEMATICAL MODELLING}

Mathematical design of PV electrical characteristics is considered to design photovoltaic module and simulated using MATLAB environment.

\subsection{Open circuit voltage}

The PV model, open-circuit voltage is represented in $\mathrm{V}_{\mathrm{OC}}$, is the voltage calculated in PV cell at zero current. The following (1) is used for calculating open circuit voltage of PV cell.

$$
V=\frac{N K T}{Q} \operatorname{in} \frac{I_{L}-I_{O}}{I_{O}}+1 \text { Volt }
$$

\subsection{Light generated current (radiation)}

It involves two major processes. The first process is the preoccupation of incident photons to produce electron-hole pairs. A second process, the assembly of these carriers in the $p$ - $n$ junction, stops this recombination by using a $p-n$ junction to spatially be isolated the electron and the hole in (2).

$$
\mathrm{I}_{\mathrm{L}}=\frac{\mathrm{G}}{\mathrm{G}_{\mathrm{ref}}} *\left(\mathrm{I}_{\mathrm{Lref}}+\alpha_{\mathrm{Isc}}\left(\mathrm{T}_{\mathrm{c}}-\mathrm{T}_{\mathrm{c} \mathrm{ref}}\right)\right)
$$

\subsection{Reverse saturation current}

The following (3) and (4) has been used for calculating reverse saturation current of PV cell.

$$
\mathrm{I}_{\mathrm{o}}=\mathrm{I}_{\mathrm{or}} *\left(\mathrm{~T} / \mathrm{T}_{\mathrm{ref}}\right)^{3} \exp \left(\left(\frac{\mathrm{QE} g}{\mathrm{KN}}\right) *\left(\frac{1}{\mathrm{~T}_{\mathrm{r}}}-\frac{1}{\mathrm{~T}}\right)\right)
$$

and

$$
\mathrm{I}_{\mathrm{o}}=\mathrm{I}_{\mathrm{or}} *\left(\mathrm{~T} / \mathrm{T}_{\mathrm{ref}}\right)^{3} \exp \left(\left(\frac{\mathrm{QEg}}{\mathrm{KN}}\right) *\left(\frac{1}{\mathrm{~T}_{\mathrm{r}}}-\frac{1}{\mathrm{~T}}\right)\right)
$$

\subsection{Short circuit current}

$I s h=I_{L}$. It is the extreme value of the current produced by a PV cell at zero voltage. The following equation no 5 has been used for calculating short circuit current for PV cell. Irradiation: $\mathrm{G}=$ radiation $\mathrm{W} / \mathrm{m}^{2}$.

$$
\mathrm{I}_{\mathrm{sh}}=\mathrm{I}_{\mathrm{L}}-\mathrm{I}_{\mathrm{o}}\left(\left(\exp \mathrm{e}^{\left(\mathrm{Q} \frac{\mathrm{V}-\mathrm{IR}_{\mathrm{S}}}{\mathrm{NKT}}\right)}-1\right)\right.
$$

\subsection{Incremental conduction based mppt on PV system}

The Incremental Conductance (INC) method is very commonly used for MPPT technology for photovoltaic array [12]. The INC technology will operate based on the relation between PV terminal voltage and maximum power point voltage. The current has played the important role in PV output power because the PV cell is current source and output power is $\mathrm{P}=\mathrm{V}^{*} \mathrm{I}$.

$$
\frac{d p}{d v}=1+V \frac{d i}{d v}
$$

The photovoltaic array output characteristics depend upon the following condition When $\frac{d p}{d v}>0$. Voltage is less than MPP voltage $\mathrm{V}_{\max }$.

When $\frac{d p}{d v}<0$. Voltage is more than MPP voltage $\mathrm{V}_{\max }$.

When $\frac{d p}{d v}=0$. Voltage is equal to MPP voltage $\mathrm{V}_{\max }$.

The above conditions are judged and regulate the operating voltage and achieve the maximum powergeneration using INC. Figure 1 shows the photovoltaic array VI characterises 

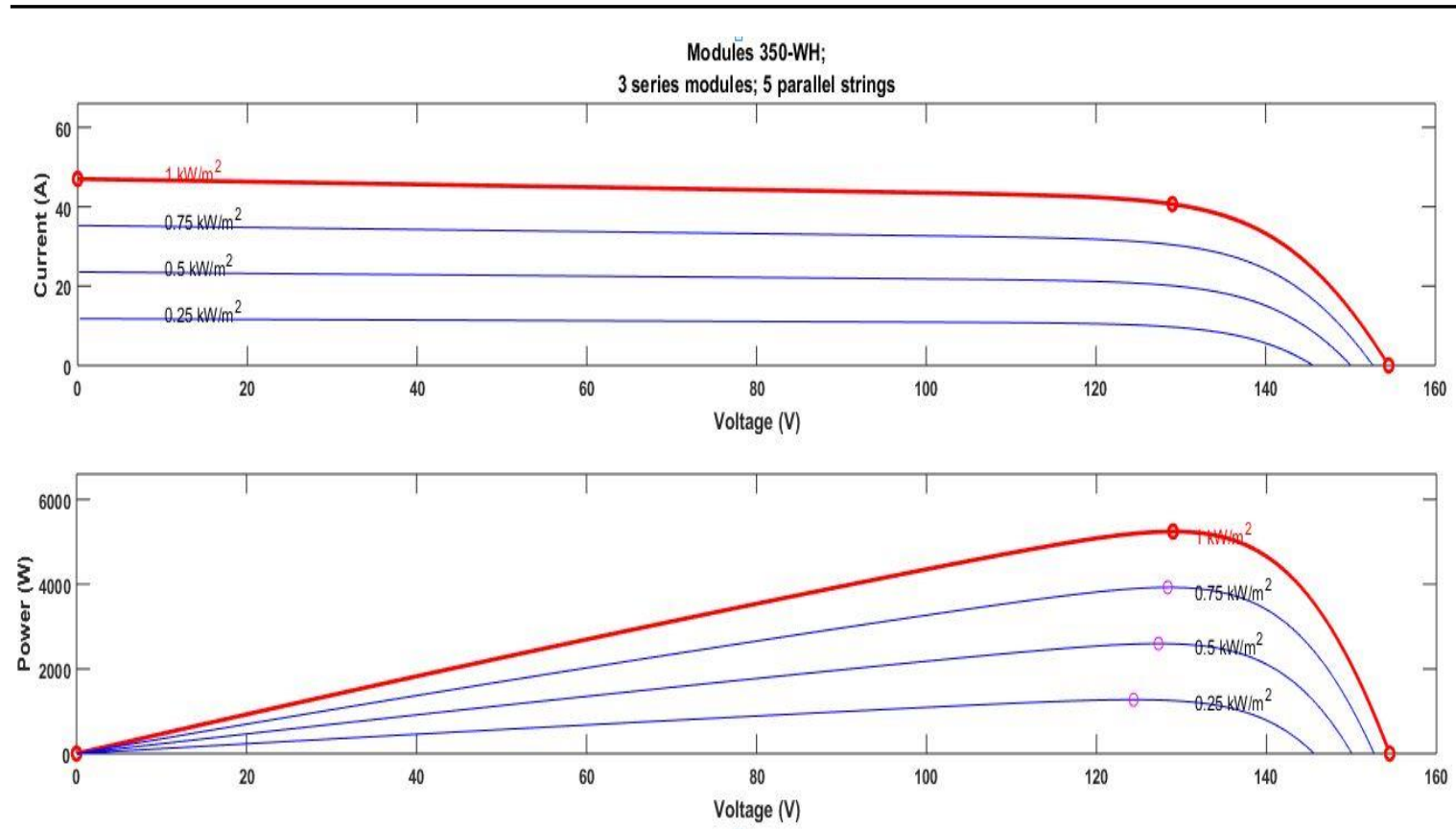

Figure 1. Photovoltaic array VI characterises

\section{NEW 9 LEVEL CASCADE H-BRIDGE MULTILEVEL INVERTER FOR PV SYSTEM}

The simulation model consists of 12 MOSFET power electronic switches in which eight MOSFET M1 to M8 connect to the four separate PV array PV1 to PV4 which forms the 4 level DC to DC converter as shown in Figure 2b. MOSFET 1 to MOSFET 4 form the H-Bridge Inverter which cascaded with the DC to DC converter. The triggering pulses for the MOSFETs are given by the respective pulse generators. The switching status of the converter and the H-Bridge is given. The 9 Level output voltage of proposed multilevel inverter is presented in Figure 3 and its THD value is presented in Figure 4. Voltage Rating of Single PV array is $155(\mathrm{~V})$. Total Output voltage is PV1+PV2+PV3+PV4 $=600(\mathrm{~V})$.

The proposed system the staircase modulation structure has been used for CMHB inverter is presented in Figure 2a [1]. The staircase modulation approach uses the adjacent voltage level to generate the desired reference phase voltage. This scheme is easy to implement in advance controller and this scheme are mostly used in high power low voltage multilevel inverter applications. The selected harmonics elimination PWM equation of modulation index ma can be calculated by equation. Ma $=\alpha / \mathrm{H} . \mathrm{E}$ Where, $\mathrm{H}-\mathrm{Number}$ of $\mathrm{h}$ bridge cells, E-DC voltage for each cell.

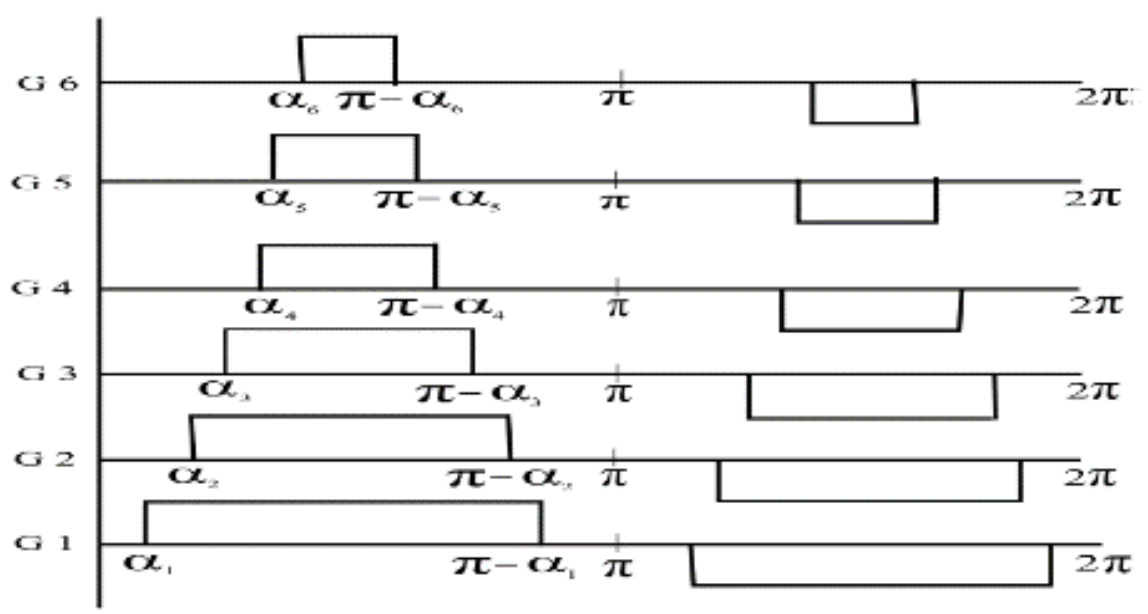

Figure 2a. Staircase modulation scheme for CMHB 
9 Level Cascade Multilevel Inverter using PV system

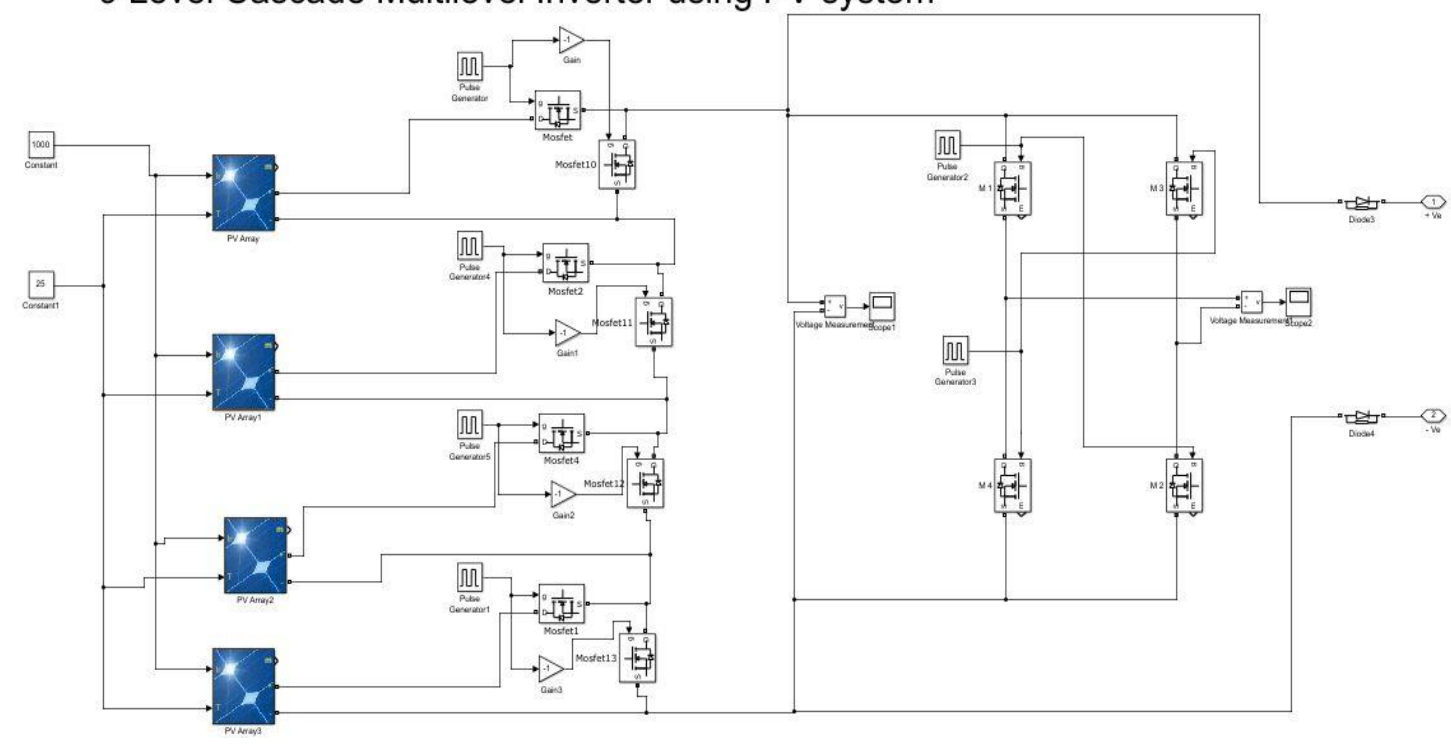

Figure 2b. Simulation of 9 levels CMHB inverter for PV power system

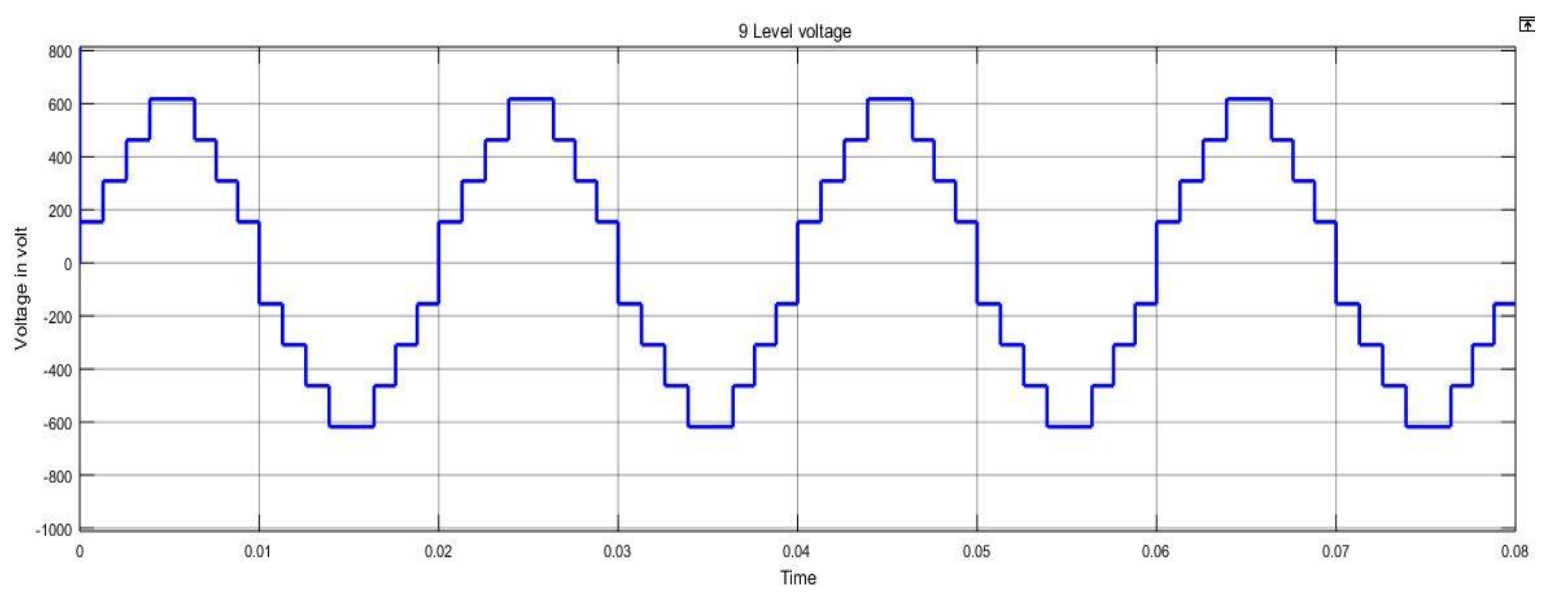

Figure 3. 9 levels CMHB inverter for PV power system output voltage waveform

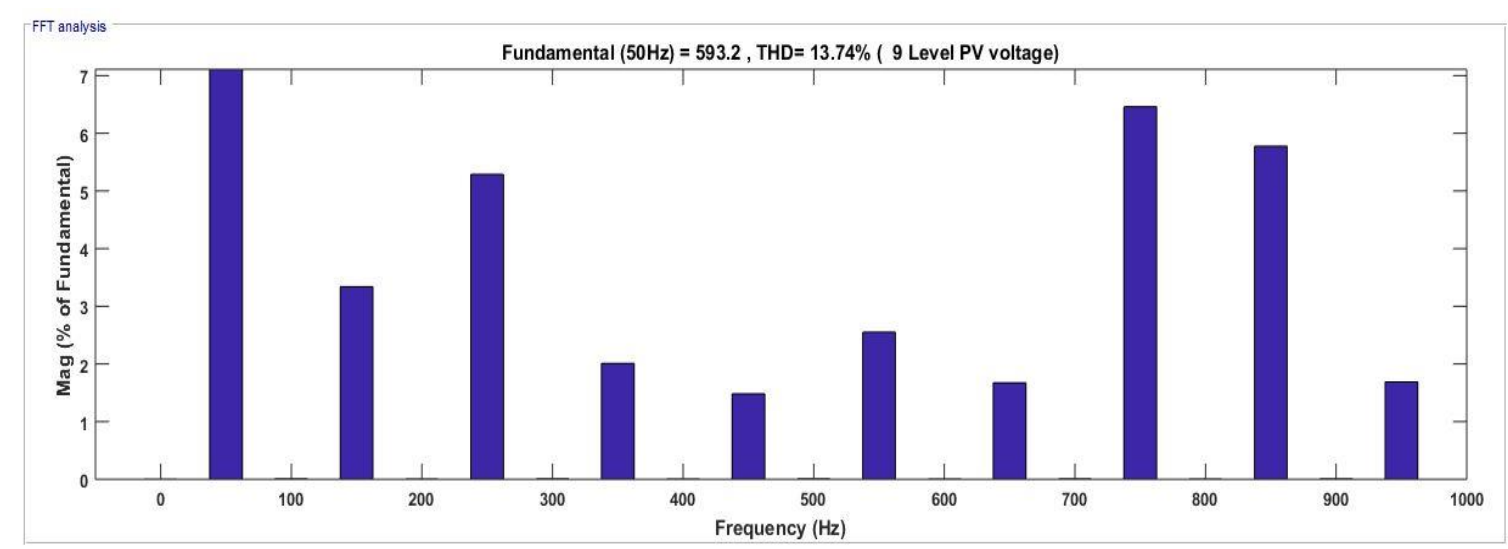

Figure 4. THD of 9 levels CMHB inverter for PV Power system 


\section{GRID INTEGRATION OF PHOTOVOLTAIC POWER SYSTEM}

Thus, the simulation of the microgrid connected distributed PV power system is shown in Figure 5. Four PV panels are considered as a distributed solar generation is connected to 9 level CMHB inverter.

\section{Grid Integration of PV system using 9 Level Multilevel Inverter}

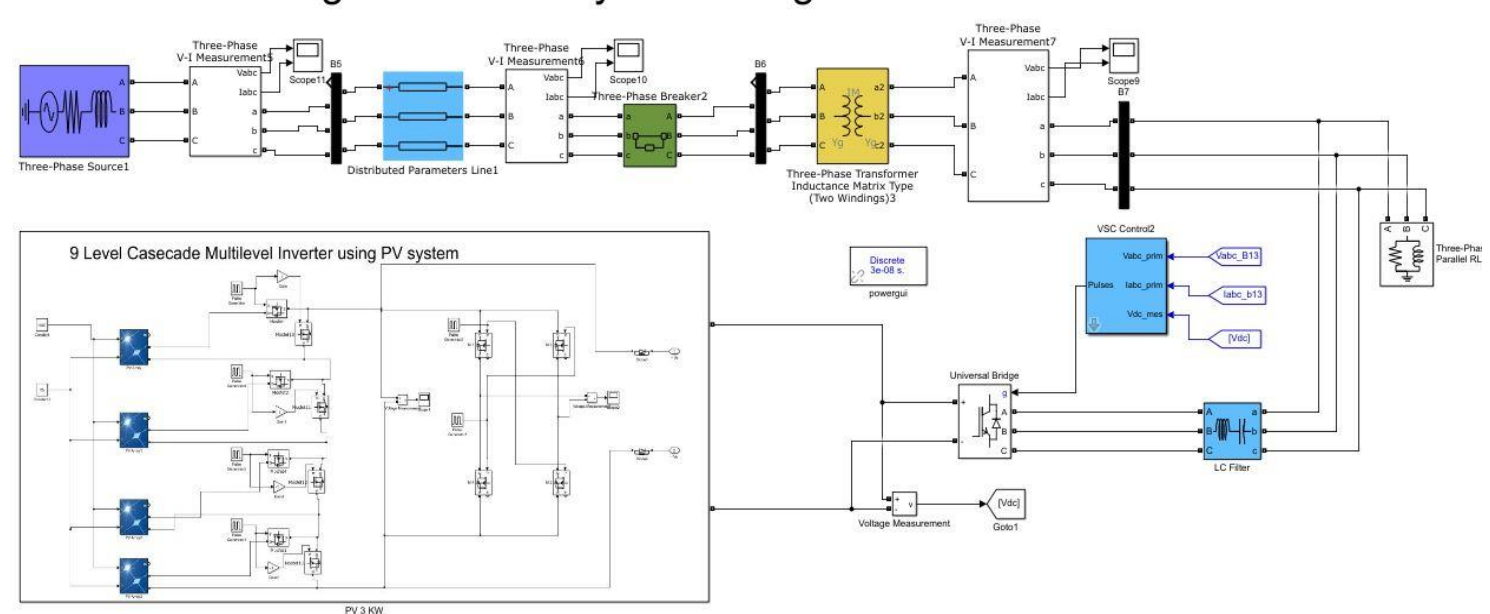

Figure 5. Grid integration of 9 level CMHB inverter for PV power system

The ANFIS rule sets are framed to maintain the PCC voltage, i.e. output voltage of the 9-level CMHB inverter to synchronize with the grid voltage. The simulation model consists of twelve MOSFET power electronics switches in which eight MOSFET such as $\mathrm{M}_{1}$ to $\mathrm{M}_{8}$ are connected to the four separate PV arrays PV1 to PV4 which forms the 4 level DC to DC converter. MOSFET 1 to MOSFET 4 form the $\mathrm{H}$-Bridge Inverter which cascaded with the DC to DC converter. The triggering pulses for the MOSFETs are given by the respective pulse generators. To reduce the harmonics LC filter is used. Finally generated 9 level output voltage for the above proposed system and THD as shown in Figure 3 and Figure 4.

\subsection{Anfis based voltage source converter controller}

The proposed ANFIS controller of voltage source converter for microgrid integration of 9 level photovoltaic inverters is presented in Figure 6. The planned controller has four major subdivisions such as 1. Phase lock Loop 2. Voltage regulator 3. Current regulator 4. PWM generator. Phase Lock Loop is an electronic circuit which has a voltage-controlled oscillator and current controlled oscillator as shown in Figure 7. Which are produced sinusoidal output signals and changes its frequency in response to the amplitude variations of the input signals. Voltage regulator circuits which are used to regulate voltage deviations with respect to variations of the input signals. Finally, the voltage regulator generates the reference value of the direct axis current $\left(\mathrm{I}_{\mathrm{d}}\right)$ as shown in Figure 8. ANFIS controller based current regulator circuit has been developed in Matlab presented in Figure 9.

vSC Main Controller

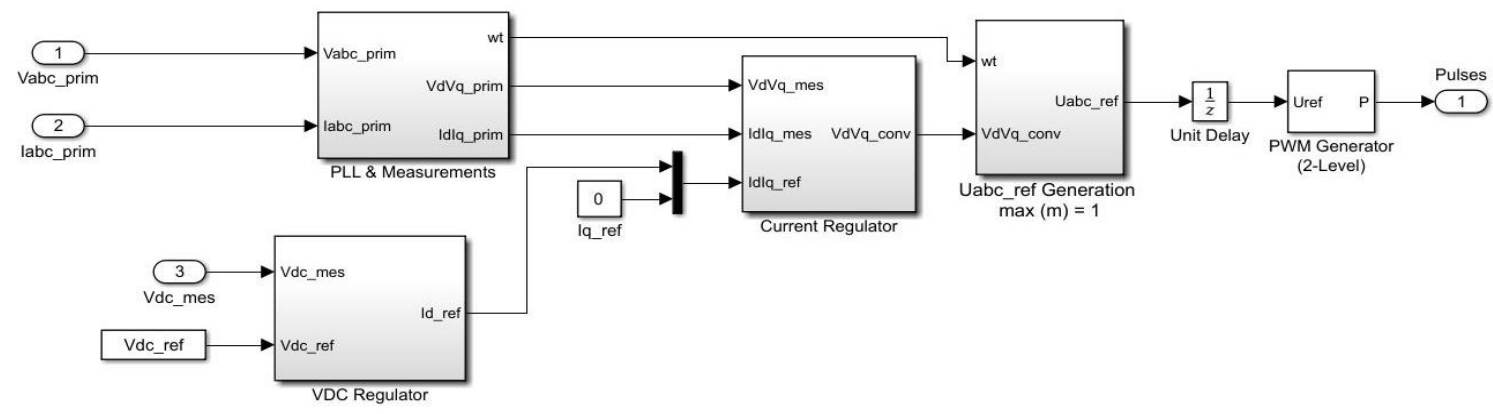

Figure 6. Design of voltage source converter's controller 


\section{Phase Lock Loop}

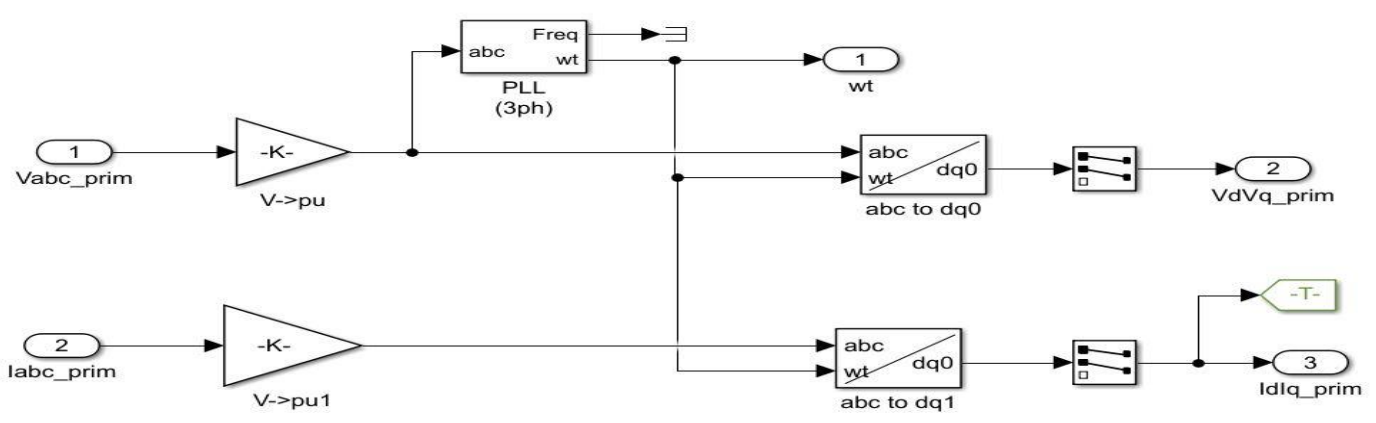

Figure 7. Design of Phase lock loop

\section{Voltage Regulator}

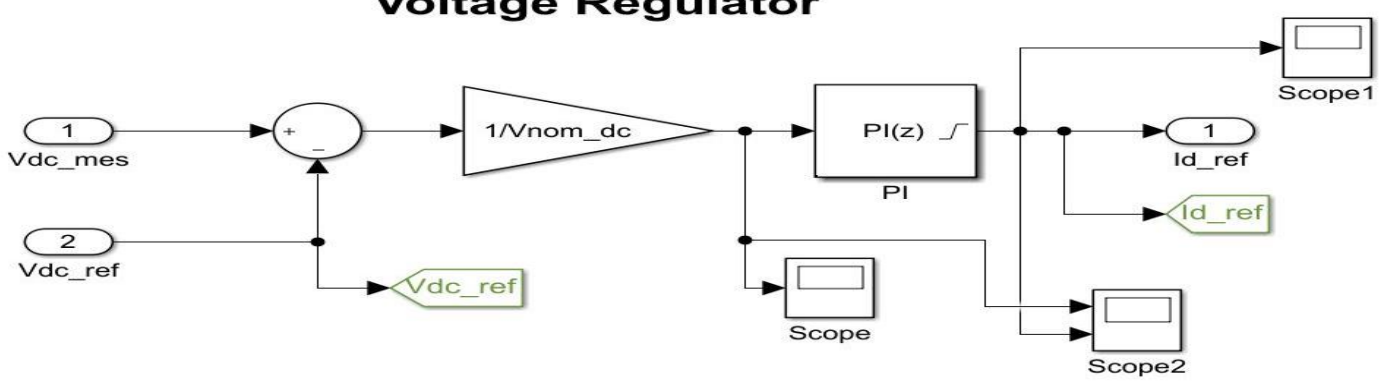

Figure 8. Design voltage regulator for grid integration of PV system

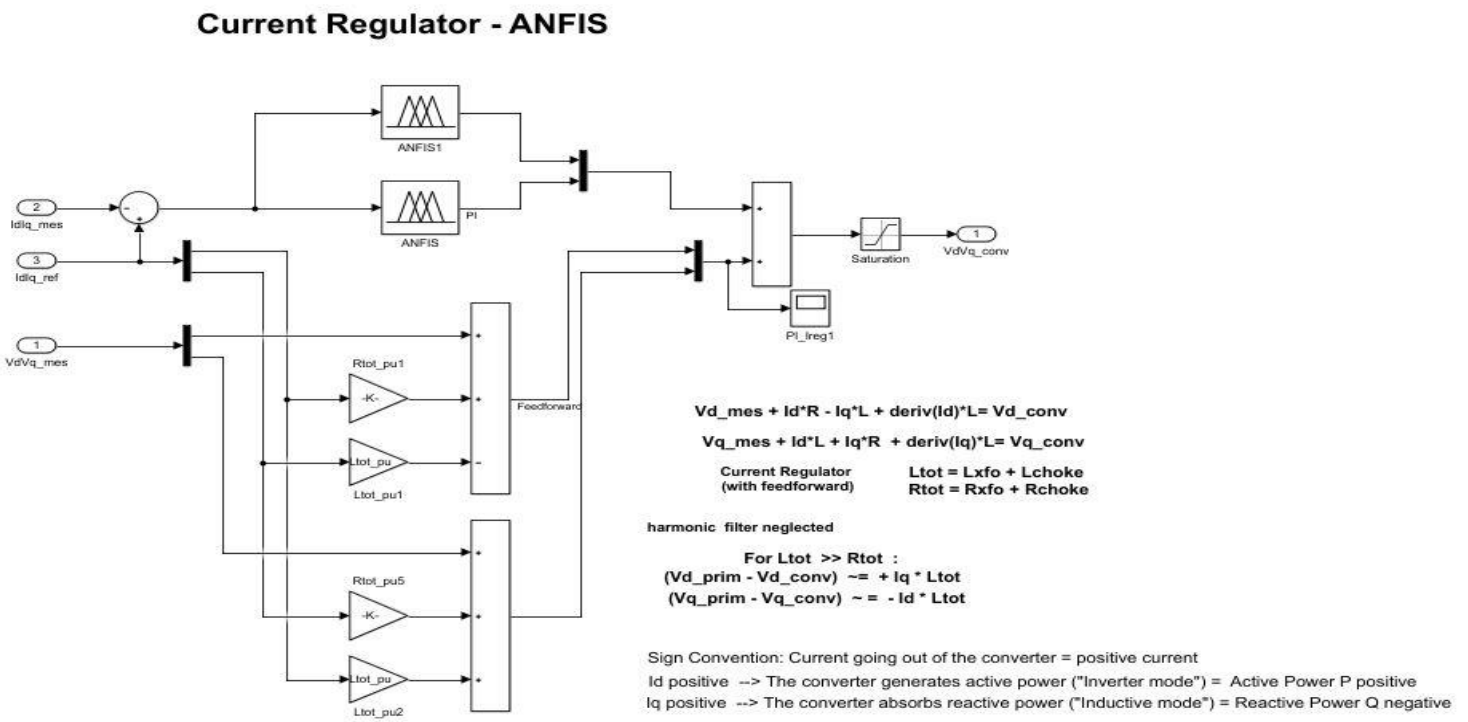

Figure 9. Design current regulator for grid integration of PV system

The proposed controller has a combination of two major controllers such as ANN and Fuzzy. The ANN controller has been used for training data and generate output based on training and target. Finally, ANN produce Fuzzy input and output membership functions presented in Figure 10. The ANN training data are measured Id and Iq currents and output of ANN controller is generated the regulated Id and Iq currents with respected to training. The ANN controller generates based on output signals, the fuzzy controller input membership functions such as Id and Iq are created as shown in Figure 11 and Figure 12. Based on input

Intelligent controller based power quality improvement of microgrid integration of... (Gaddala Jayaraju) 
membership functions the fuzzy output has been developed as shown in Figure 13. Finally, with respect to input and output membership function the fuzzy rules are formed automatically using Sugeno method as shown in Figure 14.

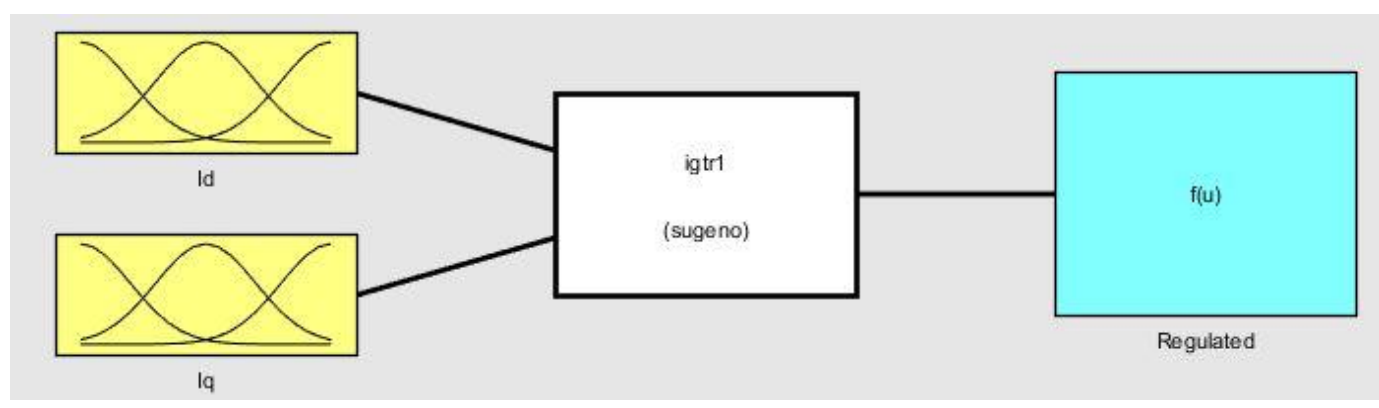

Figure 10. Design of ANFIS controller based current regulator

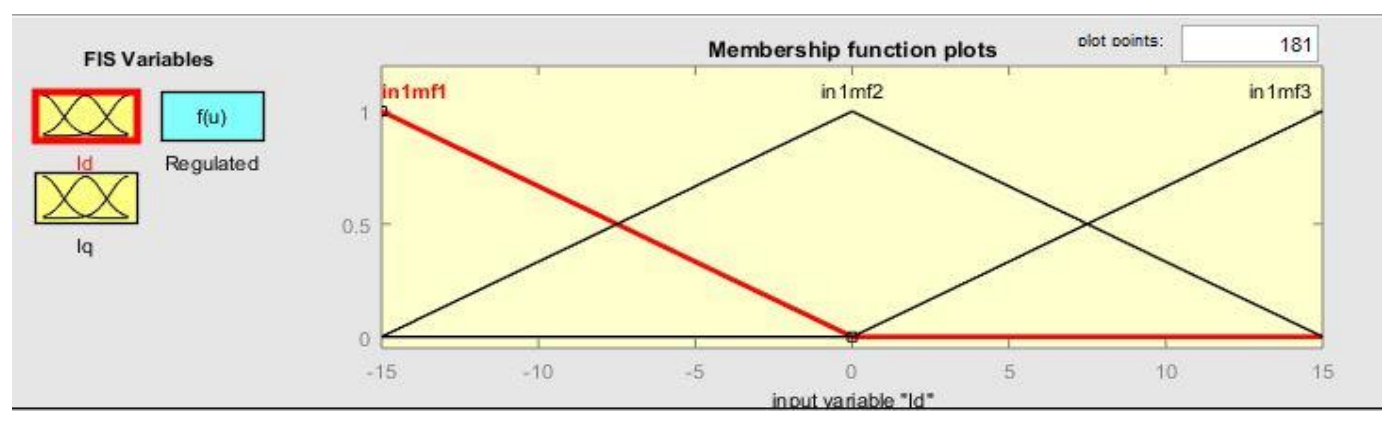

Figure 11. ANFIS input membership function for Id (current)

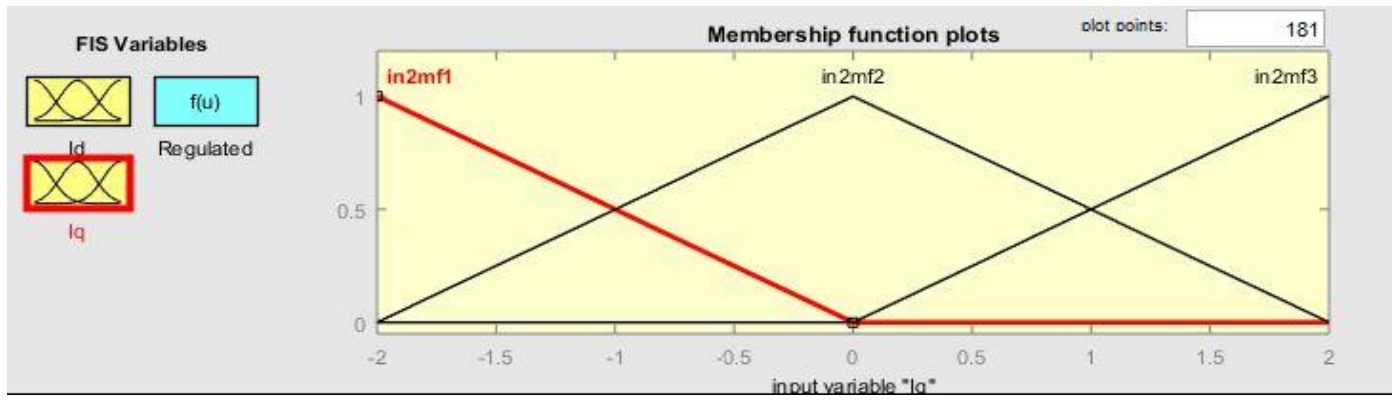

Figure 12. ANFIS input membership function for Iq (current)

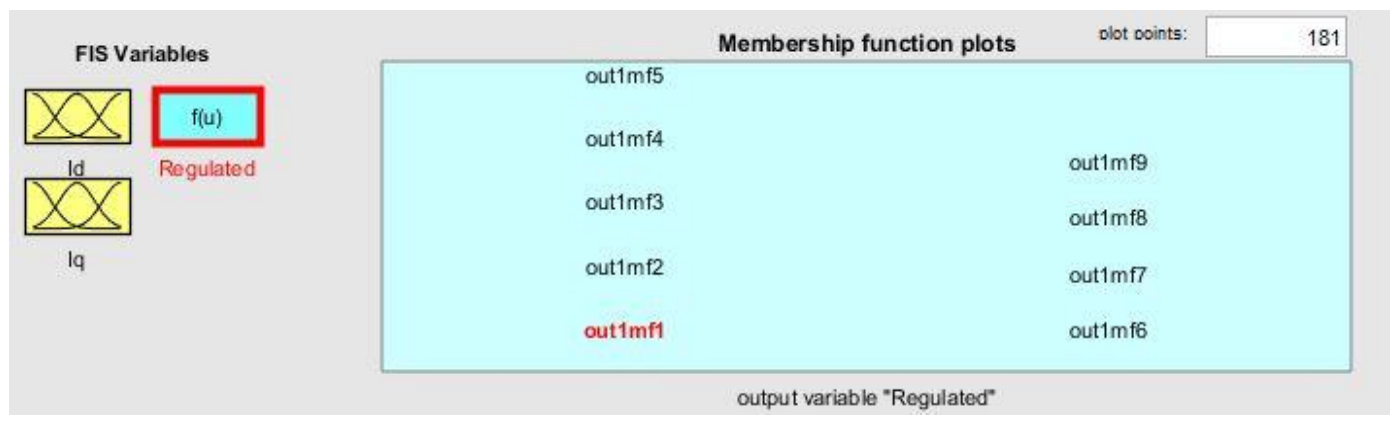

Figure 13. Output membership function of current regulator 

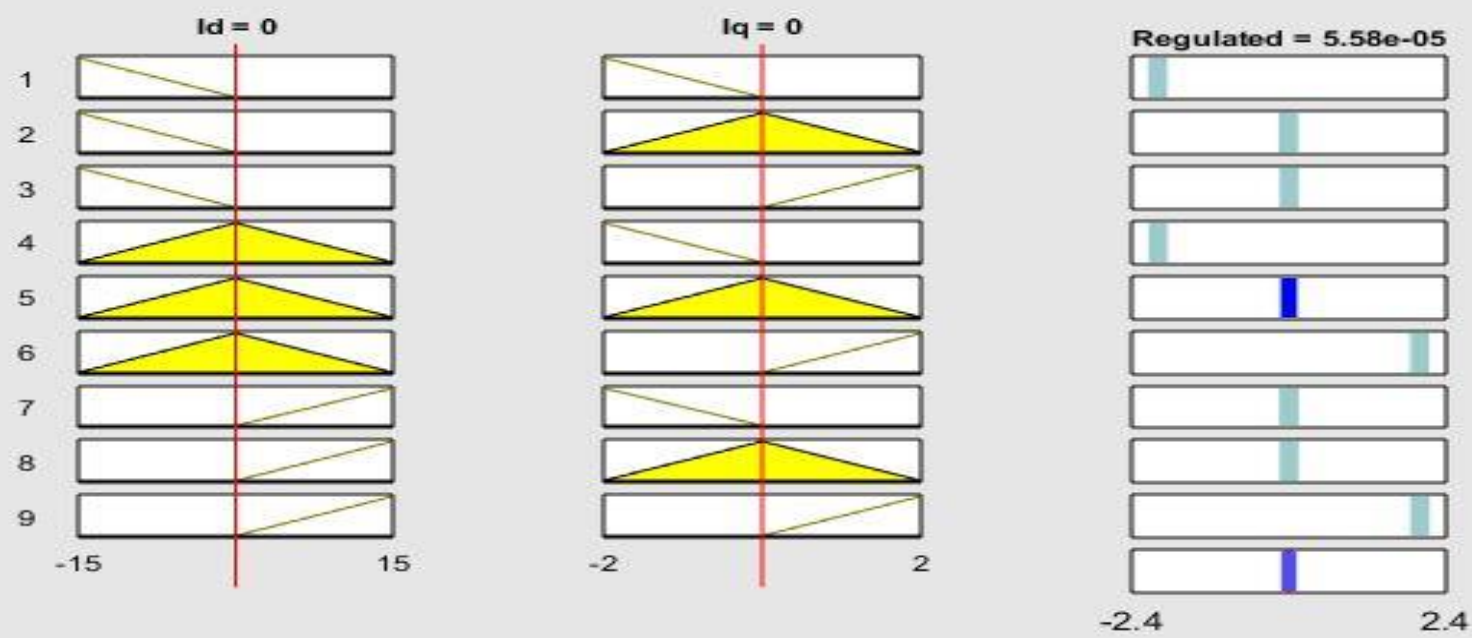

Figure 14. ANFIS rules for current regulator

The ANFIS output is connected into feed forward current regulator circuit of the converter. Based on the input signal current regulator regulate current and this regulated current value is connected into PWM generator, which is helping to generate triggering pulses of multilevel inverter for synchronize into microgrid. Figures 15 and 16 presents Voltage and Current Waveform of ANFIS controller-based grid integration of PV power system. Finally, the total harmonic distortion values are as shown in Figures 17 and 18 respectively. The THD values for the proposed system of voltage source is $0.81 \%$ and the current source is $5.57 \%$ which very compared with IEEE 1547 standard. Based on the standard value of grid integration of renewable energy source THD values less than $15 \%$ is acceptable. The proposed system THD values are very less than IEEE 1547 standard. The improvement of the power system stability as well as power quality in voltage source and current source THD values, presented then evaluated with IEEE 1547 standard presented in Table 1.

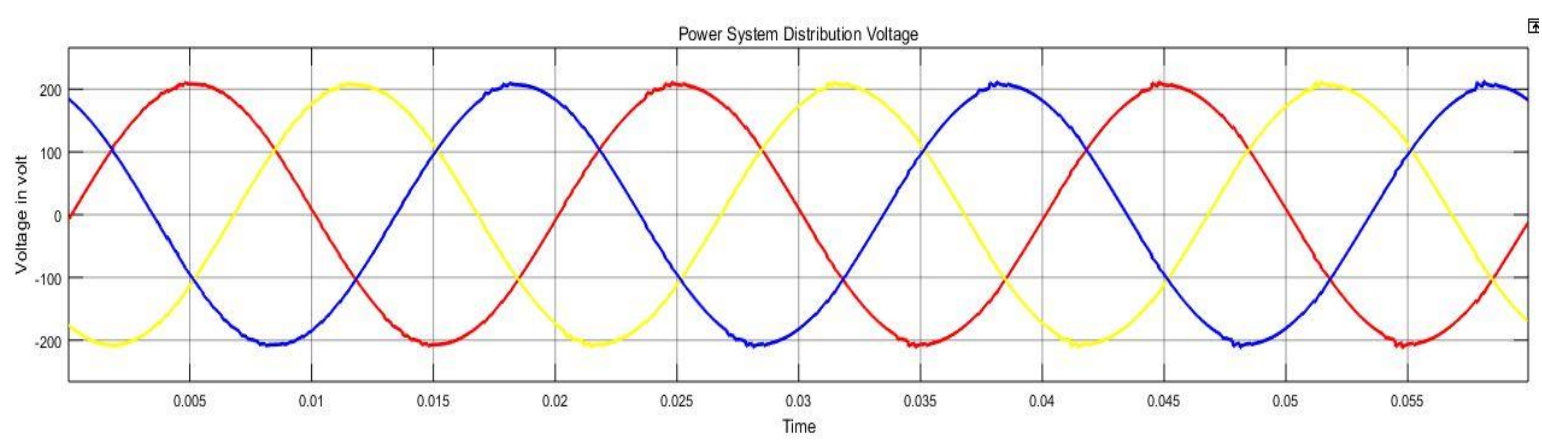

Figure 15. PV integration of Distributed grid voltage waveform

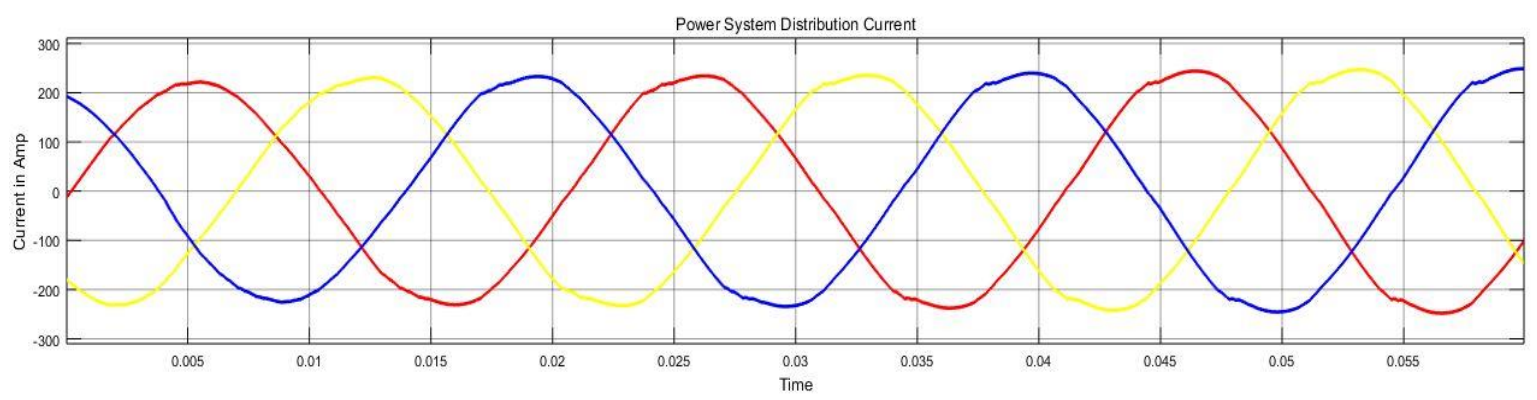

Figure 16. PV integration of Distributed grid current waveform 


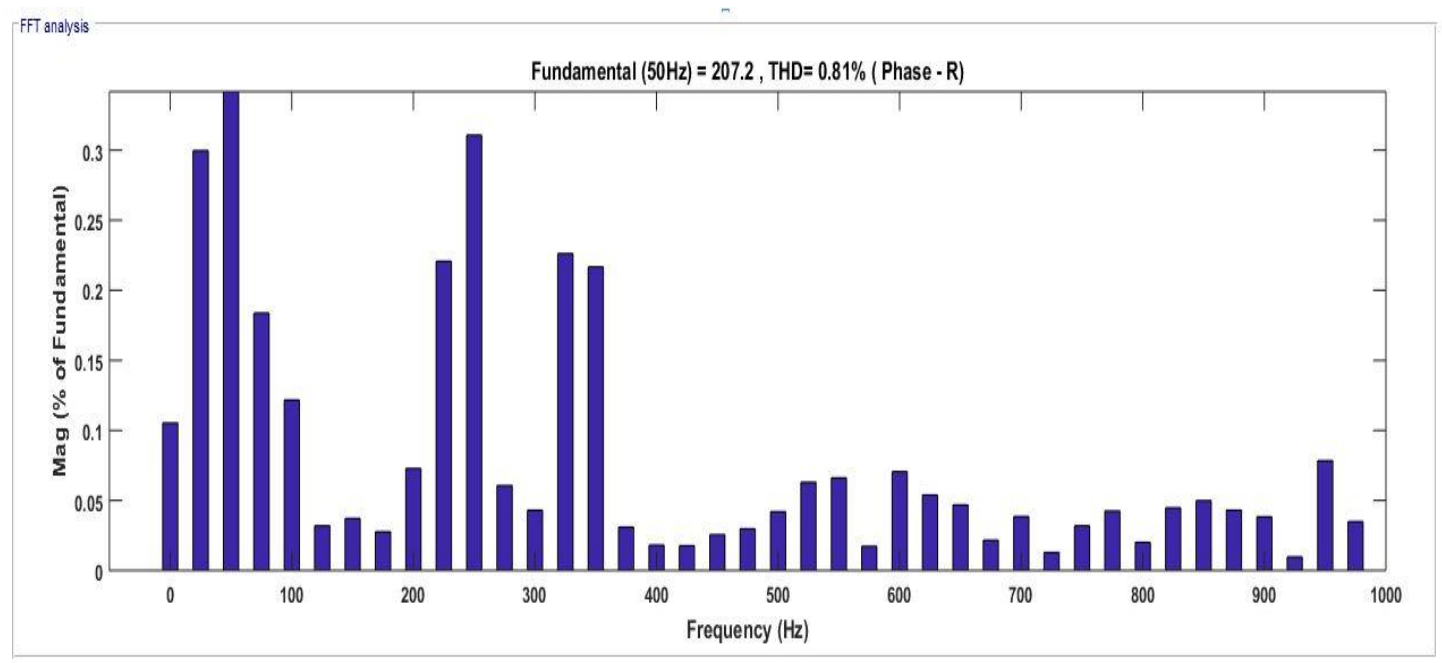

Figure 17. THD value of Distributed grid connected PV system voltage waveform

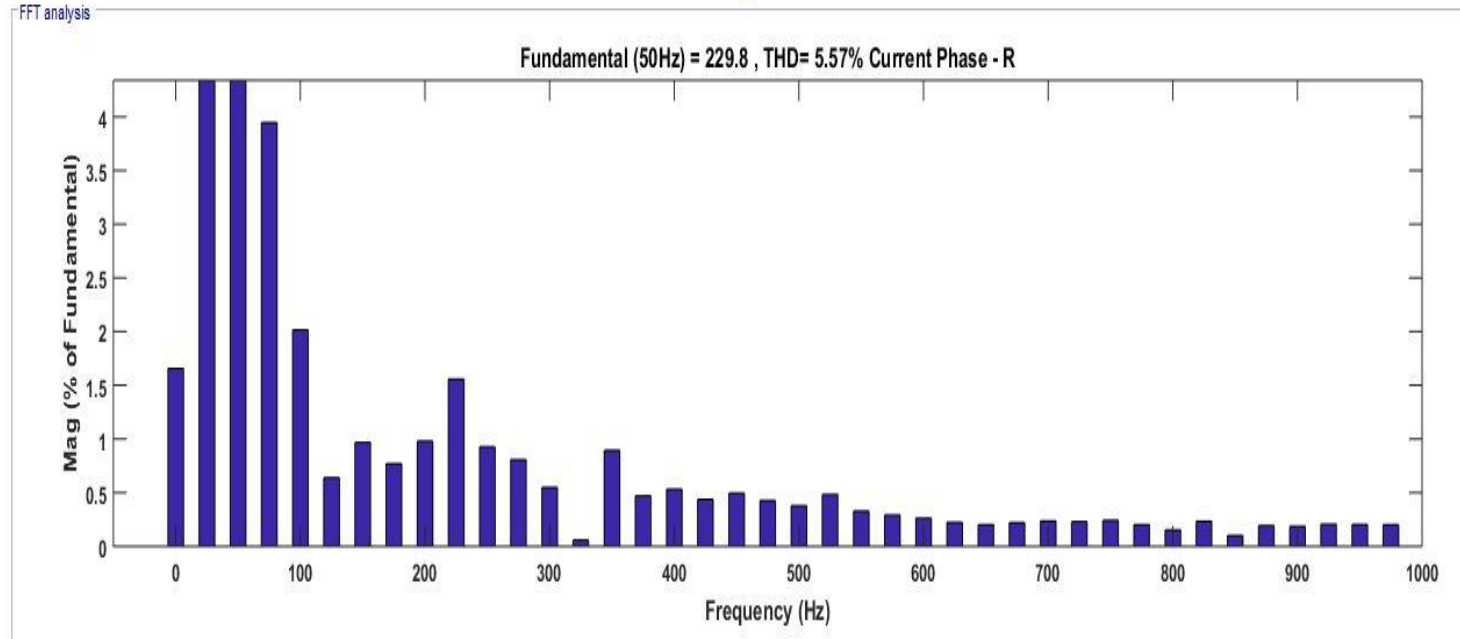

Figure 18. THD value of Distributed grid connected PV system current waveform

Table 1. IEEE 1547 Standard for Total Harmonic Distraction

\begin{tabular}{ccc}
\hline Profile & IEEE - 1547 - THD - Grid integration & Proposed design \\
\hline Voltage & $15 \%$ & $0.81 \%$ \\
Current & $15 \%$ & $5.57 \%$ \\
\hline
\end{tabular}

\section{CONCLUSION}

In this paper, modelling of a newly designed multilevel inverter topology is carried out. The mathematical study of photovoltaic systems is analyzed and simulated using Matlab. The study of the staircase modulation scheme for proposed multilevel inverter switching methodology, and analyses with asymmetrical DC source configuration. The proposed microgrid penetration of photovoltaic power system through a newly designed multilevel inverter. An analysis of ANFIS intelligent controller for proposed above microgrid system nd its performance under various conditions. The improvement of the power system stability as well as power quality in voltage source and current source THD values, presented then evaluated with IEEE 1547 standard presented in Table 1. In conclusion, based on evaluation results highlighted of proposed CMBI has been effectively operated by using ANFIS controller and this controller has been recommended for CMHB based Microgrid penetration of Photovoltaic power system. 


\section{REFERENCES}

[1] S. Jain and V. Sonti, "A Highly Efficient and Reliable Inverter Configuration Based Cascaded Multilevel Inverter for PV Systems," IEEE Transactions on Industrial Electronics, vol. 64, no. 4, pp. 2865-2875, April 2017.

[2] A. Kadam and A. Shukla, "A Multilevel Transformerless Inverter Employing Ground Connection Between PV Negative Terminal and Grid Neutral Point," in IEEE Transactions on Industrial Electronics, vol. 64, no. 11, pp. 8897-8907, Nov. 2017.

[3] S. K. Chattopadhyay and C. Chakraborty, "A New Asymmetric Multilevel Inverter Topology Suitable for Solar PV Applications With Varying Irradiance," in IEEE Transactions on Sustainable Energy, vol. 8, no. 4, pp. 1496-1506, Oct. 2017.

[4] Venkateshkumar, M., "Design of a New Multilevel Inverter Standalone Hybrid PV/FC Power System," Journal of Fuel Cells WILEY publication, 15: 862-875, 2015.

[5] Venkateshkumar, M "Fuzzy Logic Controller Based MPPT Method of the Photovoltaic Power System," International Review of Automatic Control (IREACO), vol. 7, n. 3, p. 240-244, May. 2014.

[6] B. Xiao, L. Hang, J. Mei, C. Riley, L. M. Tolbert and B. Ozpineci, "Modular Cascaded H-Bridge Multilevel PV Inverter With Distributed MPPT for Grid-Connected Applications," in IEEE Transactions on Industry Applications, vol. 51, no. 2, pp. 1722-1731, March-April 2015.

[7] M.Venkateshkumar, "Review on various Multilevel Inverter topologies for Renewable Energy Sources," International Journal of Applied Engineering Research, ISSN 0973-4562 Vol. 10 No.4, 2015.

[8] J. Selvaraj and N. A. Rahim, "Multilevel Inverter For Grid-Connected PV System Employing Digital PI Controller," in IEEE Transactions on Industrial Electronics, vol. 56, no. 1, pp. 149-158, Jan. 2009.

[9] S. Daher, J. Schmid and F. L. M. Antunes, "Multilevel Inverter Topologies for Stand-Alone PV Systems," in IEEE Transactions on Industrial Electronics, vol. 55, no. 7, pp. 2703-2712, July 2008.

[10] S. Umashankar, T. S. Sreedevi, V. G. Nithya, and D. Vijayakumar, "A New 7-Level Symmetric Multilevel Inverter with Minimum Number of Switches," ISRN Electronics, vol. 2013, Article ID 476876, 9 pages, 2013.

[11] Swaminathan G, Umashankar. S, Ramesh V, "Hybrid Control of Microgrid with PV, Diesel Generator and BESS", International Journal of Renewable Energy Research, 7 (3), pp. 1317-1323. 2017.

[12] Lijun Qin, Xiao Lu, "Matlab/Simulink-Based Research on Maximum Power Point Tracking of Photovoltaic Generation," Physics Procedia, Volume 24, Part A, 2012.

\section{BIOGRAPHIES OF AUTHORS}

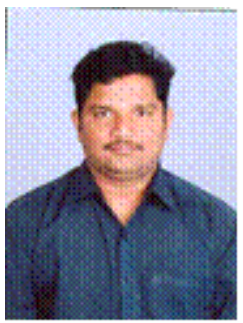

Gaddala Jayaraju received his B. Tech degree in Electrical \& Electronics Engineering from NIT,Warangal, India in 2003 and M. Tech with electrical power system management from jamia millia islamia(central university),Newdelhi, India in 2005. He is pursuing Ph.D in power quality improvement of grid connected hybrid distribution using power electronic converters at University College of Engineering \& Technology Acharya Nagarjuna University, Nagarjuna Nagar, Guntur-522 510, Andhra Pradesh, India. He is a life member of the Indian Society for Technical Education.

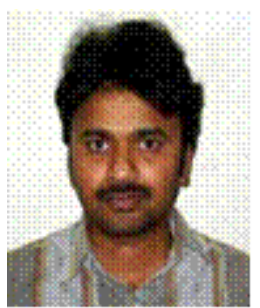

Dr.Gudapati Sambasiva Rao received B.E. degree in Electrical \& Electronics Engg., M.E. degree in Power Electronics \& Industrial Drives and his doctorate in industrial drives. Since 2006, he has been with R.V.R \& J. C. College of engineering, Guntur-522019, India. His research interests are Power Electronics, Electrical Drives, FACTS controllers, Power Quality Improvement. 